\title{
CLUSTERS AND SMALL AND MEDIUM-SIZED ENTERPRISES IN REGIONS OF THE SLOVAK REPUBLIC
}

\author{
Katarína Král'ová 268 \\ https://doi.org/10.31410/itema.2018.735
}

\begin{abstract}
In developed economies, small and medium-sized enterprises are one of the cornerstones of the economy. They make the flexible introduction of new products, increasing innovation activities. They contribute to the expansion of the competitive environment and are an irreplaceable source of economic growth. They provide progressive solutions and contribute to the creation of new job opportunities and thus to a decrease in unemployment. What is a very important fact for today's economies based on knowledge and innovation is the efficient use of environmental resources and the reduction of unemployment. Therefore, individual states support the creation of various SME support tools, such as the creation of business networks clusters. In our contribution we will analyze the situation in the regions of the SR in terms of the functionality of the clusters and the benefits of these networks for small and medium enterprises and regional development.
\end{abstract}

Keywords: small and medium enterprises, clusters, networks, region, regional development

\section{INTRODUCTION}

$\mathrm{S}$ mall and medium-sized enterprises (SMEs) are specific. SMEs are characterized by a high degree of flexibility and a faster reaction time to adapt to changing market conditions. In today's dynamically changing business environment, which is influenced by many factors, the importance of small and medium-sized businesses is steadily rising. For the national economy, small and medium-sized enterprises represent significant potential because they have a number of important functions (e.g. social, economic, innovation, education, etc.) The importance of small and medium-sized enterprises now exceeds the national level and has an international dimension. That is why we can say that small and medium-sized enterprises represent the basic economic support of the EU. Small and mediumsized enterprises are one of the most important parts of the economy:

- are an irreplaceable source of growth,

- have a high innovation and development potential,

- contribute to the flexible introduction of new products,

- contribute to increasing innovation activities,

- contribute to the development of a competitive environment,

- are the carriers of progressive solutions,

- are creating new job opportunities, thereby mitigating unemployment,

- quickly adapt and are responsive to change. [8]

The development of small and medium-sized enterprises is closely related to the level and quality of the business environment in the individual regions of the economy.

\footnotetext{
${ }^{268}$ Alexander Dubček University in Trenčín, Faculty of Social and Economic Relations, Študentská 3, 91150 Trenčín, Slovakia
} 
A high-quality business environment with the ability to achieve long-lasting economic growth is a prerequisite for business prosperity and increasing the competitiveness of all market players.

\section{SMALL AND MEDIUM-SIZED ENTERPRISES IN THE REGIONS OF THE SLOVAK REPUBLIC IN FIGURES}

By analyzing the development of the number of small and medium-sized enterprises in SR we find that since 2006 there was a growing tendency. This development in the Slovak Republic was maintained until 2011. After 2011, the total number of small and medium-sized enterprises is characterized by different developmental trends. The size structure of the business sector in the Slovak Republic is, in some respects, copying the size structure of enterprises in other EU Member States. As in the EU and in the Slovak Republic, the higher the representation of microenterprises is the characteristic feature of the business sector.

Table 1: Development of the number of small and medium - sized enterprises in the Slovak

Republic in 2006 - 2017

\begin{tabular}{|l|c|c|c|c|c|c|}
\hline & \multicolumn{7}{|c|}{ The development of small and medium-sized enterprises } \\
\hline year & $\mathbf{2 0 0 6}$ & $\mathbf{2 0 0 7}$ & $\mathbf{2 0 0 8}$ & $\mathbf{2 0 0 9}$ & $\mathbf{2 0 1 0}$ & $\mathbf{2 0 1 1}$ \\
\hline SMEs & 481028 & 500557 & 537481 & 540617 & 552725 & 555608 \\
\hline year & $\mathbf{2 0 1 2}$ & $\mathbf{2 0 1 3}$ & $\mathbf{2 0 1 4}$ & $\mathbf{2 0 1 5}$ & $\mathbf{2 0 1 6}$ & $\mathbf{2 0 1 7}$ \\
\hline SMEs & 551608 & 563501 & 565241 & 531063 & 557122 & 567131 \\
\hline
\end{tabular}

Source: SBA, based on data from the Register of Organizations of the Slovak Statistical Office

The basic quantitative indicator characterizing the overall quality of business conditions in the economy is the number of small and medium-sized enterprises. According to data of the Statistical Office of the Slovak Republic, the year-on-year increase of the total number of active small and medium-sized enterprises was recorded by $1.8 \%$. The business environment of the individual EU countries differs, and so the conditions for doing business in the different regions of the Slovak Republic differ. These differences lead to the uneven development of small and medium-sized enterprises in the regions of the Slovak Republic. What is also reflected in the values of selected quantitative indicators of small and medium-sized enterprises at the level of individual regions (NUTS 3 territorial unit)? Every fifth $(22.3 \%)$ active small and mediumsized enterprise (including FO - entrepreneurs) operates within the Bratislava Region. In other regions of Slovakia, the representation of SMEs is substantially more even. After the Bratislava Region, the most small and medium-sized enterprises are located in the territory of the Žilinský region with a share of $13.4 \%$. The lowest representation of SMEs, at $9.6 \%$, was registered in Trenčín in 2017. The geographic distribution of small and medium-sized enterprises in the economy significantly affects the development of individual regions as well as the competitiveness of the regions. We must realize that each region is unique. And in this context, it is necessary to strengthen individual regions and allow them to use their strengths. A competitive region is just one that can offer businesses and people an attractive and sustainable environment for life, work and business. 
Table 2: Representation of small and medium-sized enterprises by region of Slovakia in 2017

\begin{tabular}{|l|c|c|c|c|c|}
\hline \multicolumn{1}{|c|}{ region of Slovakia } & SMEs & $\%$ & $\begin{array}{c}\text { large } \\
\text { businesses }\end{array}$ & $\%$ & together \\
\hline $\begin{array}{l}\text { Bratislava region } \\
\text { BA }\end{array}$ & 126464 & $22,3 \%$ & 217 & $32,8 \%$ & 126681 \\
\hline Trnava region TT & 56559 & $9,9 \%$ & 57 & $8,6 \%$ & 56616 \\
\hline Trenčín region TN & 54273 & $9,6 \%$ & 92 & $13,9 \%$ & 54365 \\
\hline $\begin{array}{l}\text { Nitra region NR } \\
\text { Zilina region ZA }\end{array}$ & 68947 & $12,2 \%$ & 61 & $9,2 \%$ & 69008 \\
\hline $\begin{array}{l}\text { BánskaBystrica } \\
\text { region BB }\end{array}$ & 56650 & $19,4 \%$ & 75 & $11,4 \%$ & 76274 \\
\hline Prešov region PO & 70616 & $12,5 \%$ & 48 & $7,3 \%$ & 56698 \\
\hline Košice region KE & 57423 & $10,1 \%$ & 56 & $8,5 \%$ & 70672 \\
\hline together: & 567131 & $100 \%$ & 661 & $8,3 \%$ & 57478 \\
\hline
\end{tabular}

Source: Small and medium-sized enterprises in numbers in 2017, SBA Bratislava 2018.

Every three years the European Union assesses the competitiveness of the regions in the EU. It evaluates the 263 regions of the European Union through the index of regions' competitiveness, which counts on scores of indicators assessing the quality of institutions, macroeconomic stability, infrastructure availability, population health, education, market size, labor market, technology development and maturity of the business sphere.

Table 3: Competitiveness Index of SR Regions (year 2016)

\begin{tabular}{|l|c|c|c|c|}
\hline & score & order & weaknesses & strengths \\
\hline Bratislava & 65,4 & 96. & $\begin{array}{c}\text { institutions, basic } \\
\text { education, health }\end{array}$ & $\begin{array}{c}\text { business sphere, innovation, higher } \\
\text { education }\end{array}$ \\
\hline western Slovakia & 33,8 & 196. & $\begin{array}{c}\text { health, institutions, } \\
\text { business sphere }\end{array}$ & $\begin{array}{c}\text { infrastructure, market size, } \\
\text { macroeconomic stability, }\end{array}$ \\
\hline eastern Slovakia & 24,0 & 225. & $\begin{array}{c}\text { health, innovation, } \\
\text { labor market }\end{array}$ & $\begin{array}{c}\text { higher education, macroeconomic } \\
\text { stability, technology }\end{array}$ \\
\hline central Slovakia & 29,7 & 211. & $\begin{array}{c}\text { health, business } \\
\text { sphere, infrastructure }\end{array}$ & $\begin{array}{c}\text { higher education, macroeconomic } \\
\text { stability, technology }\end{array}$ \\
\hline
\end{tabular}

Source: European Commission, European Regional Competitiveness Index

So, on the basis of assessing the competitiveness of the regions, we ask ourselves: "How to reduce the lagging regions of Slovakia?" In spite of the economic growth of the Slovak Republic and the rapid growth of state revenues, the less successful regions of Slovakia do not get the richer ones. The long-term unemployment is a major problem in many regions in Central and Eastern Slovakia. As a result, a substantial proportion of the adult population in these regions have lost working habits. 
Figure 1: Unemployment rate by district at 31.3.2018.

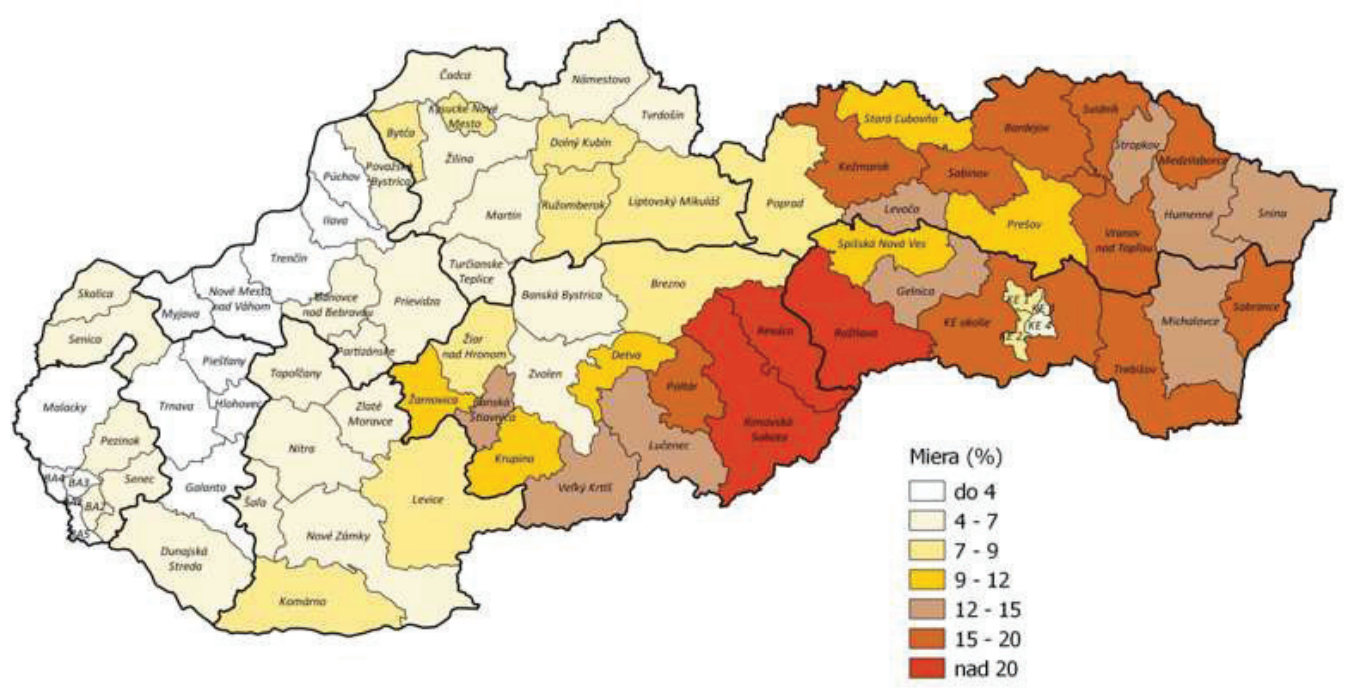

Source: Statistical Office of the SR, www.statistics.sk, the headquarters of the work of social affairs and family

Another problem of lagging regions is the quality of transport infrastructure, the lack of infrastructure, and the long-term neglect of maintenance of most existing roads. The very serious problem of lagging regions is also the low quality of the business sphere and the weak innovation activity, which has a significant impact on the competitiveness of the regions. Competitive regions generate income and maintain employment at a high level. The Slovak Republic has long been addressing problems with interregional disparities. Habánik, Koišová, [3], Gajdoš, P. [1] states that "regional disparities are the product due to several factors, depend on the quality and developing disposable potentials but also different positions from which each region entered the transition process." The settlement of interregional disparities is an important task of the SR's economic policy. Due to the influence of market forces, globalization or other economic activities, businesses tend to concentrate only in selected regions where appropriate business conditions are ensured to further diversify regional disparities. One of the effective solutions of regional disparities is support the development of clusters in regions such as Havierniková, Strunz [5] says: One possibility how to contribute to the regional development is interconnection between businesses, educational institutions and local government entities into the purpose-built configurations - clusters. Cluster business cooperation can take the form of a variety of joint activities that maintain the viability, prosperity of the region and the competitiveness of the region. The European Union defines clusters as groups of independent companies and associated institutions that cooperate and compete. They are geographically located in one or more regions or may have a global scope; specialize in a particular field and are linked by common technologies or a common qualification; are a traditional industry or are based on a scientific basis. Clusters can be institutionalized or spontaneous. They have a positive impact on innovation, competitiveness, skills upgrading, information, growth and longterm business dynamics. A part of the project was the survey and mapping of the structure of clusters in individual regions of the SR (Table 4). We processed the obtained data and evaluated the current situation in the cluster packaging in the individual regions of the SR. We have found that the SR in the area of clustering and cluster development lags behind other EU states, which is detrimental. Small and medium-sized enterprises are not interested in engaging in such initiatives, they have no confidence in such a form of mutual cooperation. They are afraid of losing their own business strategy in favor of common know-how. And the mistrust of small and medium-sized enterprises in the moral and professional quality of politicians and in politics itself is very negative too. Other problems that hamper the development of clusters are lacking 
cluster policy, inadequate legislation that would direct the cluster's work, define forms of cooperation with self-government and government, or funding. Individual institutions work separately and uncoordinated.

Table 4: List of clusters by region in Slovakia (2018)

\begin{tabular}{|c|c|c|c|c|}
\hline \multicolumn{2}{|c|}{ region } & Cluster name & establishment & Cluster type \\
\hline \multirow{3}{*}{ BA } & 1 & Dunajský vedomostný klaster & 2010 & TE \\
\hline & 2 & Národný energetický klaster - NEK & 2012 & TE \\
\hline & 3 & ABC - Academic Business Cluster & 2011 & $\mathrm{TE}$ \\
\hline \multirow{2}{*}{ BB* } & 1 & 1. slovenský strojársky klaster & 2008 & $\mathrm{TE}$ \\
\hline & 2 & Klaster pohraničných hradov & 2009 & $\mathrm{CR}$ \\
\hline \multirow{5}{*}{$\mathbf{K E}^{*}$} & 1 & BITERAP & 2004 & $\mathrm{TE}$ \\
\hline & 2 & Klaster AT+R z.p.o. & 2010 & $\mathrm{TE}$ \\
\hline & 3 & $\begin{array}{l}\text { Klaster cestovného ruchu Košice - } \\
\text { Turizmus }\end{array}$ & 2010 & $\mathrm{CR}$ \\
\hline & 4 & Klaster RADAR & 2014 & TE \\
\hline & 5 & Košice IT Valley & 2012 & $\mathrm{TE}$ \\
\hline \multirow{3}{*}{ NR } & 1 & Bioeconomy Cluster & 2015 & TE \\
\hline & 2 & $\begin{array}{l}\text { Združenie cestovného ruchu - Klaster } \\
\text { Topol’čany }\end{array}$ & 2012 & $\mathrm{CR}$ \\
\hline & 3 & Slovenský plastikársky klaster & 2009 & $\mathrm{TE}$ \\
\hline \multirow{2}{*}{ PO* } & 1 & Energetický klaster Prešovského kraja & 2015 & $\mathrm{TE}$ \\
\hline & 2 & Železničný dopravný klaster, z.z.p.o. & 2014 & $\mathrm{TE}$ \\
\hline \multirow{2}{*}{$\mathrm{TN}$} & 1 & Slovak IT Cluster & 2013 & $\mathrm{TE}$ \\
\hline & 2 & Klaster Váh & 2010 & $\mathrm{CR}$ \\
\hline \multirow{6}{*}{$\mathrm{TT}$} & 1 & Automobilový klaster Slovensko & 2007 & $\mathrm{TE}$ \\
\hline & 2 & $\begin{array}{l}\text { Elektrotechnický klaster - západné } \\
\text { Slovensko }\end{array}$ & 2008 & $\mathrm{TE}$ \\
\hline & 3 & Energetický klaster - západné Slovensko & 2009 & $\mathrm{TE}$ \\
\hline & 4 & $\begin{array}{l}\text { Klaster pre podporu inovatívnych a } \\
\text { zelených technológií -projekt }\end{array}$ & 2012 & $\mathrm{TE}$ \\
\hline & 5 & $\begin{array}{l}\text { Klaster regionálneho rozvoja - západné } \\
\text { Slovensko }\end{array}$ & 2016 & $\mathrm{CR}$ \\
\hline & 6 & Klaster Smolenice & 2010 & $\mathrm{CR}$ \\
\hline \multirow{4}{*}{$\mathrm{ZA}$} & 1 & $\begin{array}{l}\text { Klaster Liptov - združenie cestovného } \\
\text { ruchu }\end{array}$ & 2008 & $\mathrm{CR}$ \\
\hline & 2 & Klaster Orava & 2008 & $\mathrm{CR}$ \\
\hline & 3 & $\begin{array}{l}\text { Klaster Turiec - Združenie cestovného } \\
\text { ruchu }\end{array}$ & 2009 & $\mathrm{CR}$ \\
\hline & 4 & Z@ict & 2007 & TE \\
\hline
\end{tabular}

(Notes: TE - technological cluster, CR - cluster of tourism, * clusters of central and eastern Slovakia)

The total number of clusters is 27 in the SR, of which only $33 \%$ are clusters located in Central and Eastern Slovakia. It is a very low representation. Apart from this, there are only two clusters focused on tourism, while Central and Eastern Slovakia has a lot of attractions that could be 
given to tourists, in the area of historical, cultural monuments, natural delights, gastronomic experiences and so on. These potentialities of these regions have not yet been sufficiently exploited and there are reserves that can be used. These regions are characterized by economic stability; they have free labor and technology. The weakness of these regions is the quality and scale of infrastructure, the quality of the business environment, qualified workforce, investment. The number of these barriers in the development of business activities in these regions could be solved by business networks - clusters that allow small and medium enterprises, for example:

- economies of scale,

- cost sharing,

- sharing research and investment results,

- participation in joint projects and exploitation of their results,

- improving the image of the business,

- increasing the innovative performance of an enterprise,

- supply chain optimalization,

- new customers, opening new markets,

Cluster benefits for the region:

- in the region of the cluster, there is a concentration of specialized suppliers,

- improving the image of the region and landscape,

- increasing the innovation performance of the region and the countryside,

- more efficient use of regional resources,

- creation of jobs,

- more efficient use of the region's natural resources,

- restructuring and development of the regional economy,

- lobbying to improve legislation, subsidy policy.

\section{CONCLUSION}

Small and medium-sized enterprises are a major factor in co-operation with large enterprises. They grow faster and work more intensively than large businesses. They create jobs with relatively low capital costs, and their performance is more cost-effective. They produce specialized products and also provide specialized services. They are better suited to the needs of the spatial economy and, given the relatively small segments of the market, have more prosperous sales outlets. They also have better opportunities to use technology transfer and the results of innovative processes. Small and medium-sized enterprises are significantly involved in increasing the competitiveness of the regions. This area of small and medium-sized enterprises represents a great potential for the economy, which can be further increased. This means that the interdependence of spatial structure and economic development gains importance in today's highly competitive environment. Thus, solving the problems of the current economy, economic growth, unemployment and financial stability is moving towards a new organization of the economic area by building clusters.

\section{Acknowledgements}

This paper was created within the project VEGA no. 1/0953/16 Evaluation of the impact of clusters on regional development of the Slovak Republic. 


\section{REFERENCES}

[1] Gajdoš, P. (2008) Current state and development of regional disparities in Slovakia (with emphasis on underdeveloped regions). In. Gajdoš, ed. Regional disparities in Central Europe. Sociologický ústav SAV, Bratislava, s. 98-115,

[2] Habánik, J. 2012. Klastre a inovácie v prostredí regionálnej ekonomiky. Sociálnoekonomická revue, 10(2), s. 15--23,

[3] Habánik, J., Koišová, E. Development of socio-economic disparities in regional development of the Slovak Republic. In. Nová ekonomika. Bratislava, NHF EÚ, 2012

[4] Havierniková, K. a kol. (2013). Teoreticko-metodologické aspekty merania ekonomickej výkonnosti klastrov v Slovenskej republike. Trenčín : TnUAD,.

[5] Havierniková, K., Strunz, H. The comparison of selected methods used for identification of cluster potential in the regions of the Slovak Republic, In Book Series Titles: International Multidisciplinary Scientific Conferences on Social Sciences and Arts ( SGEM 2014), 2014.

[6] Král'ová, K., Sochul'áková, J., Petrušová, D. 2017. Clusters and regional development. In 4th International Multidisciplinary Scientific Conference on Social Sciences and Arts SGEM 2017, Conference Proceedings Book 1, Vol 4, pp. 137-144.

[7] Small and medium-sized enterprises in numbers in 2017, Bratislava 2018, vydalo SBA 2018 ,

[8] Král'ová, K., 2016 Economy of small and medium-sized enterprises, Tn UAD, Trenčín, ISBN 978-80-8075-766-3

[9] Morovská, I., 2008 Možnosti podpory a rozvoja jednotlivých regiónov Slovenska prostredníctvom využitia štrukturálnych fondov. In:Zborník príspevkov z konferencie Projektový management - teórie a praxe. UTB, FMK, Zlín, pp. 29

[10] Smolková, E. - Borovský, J. 2005 Strategické partnerstvá pre malé a stredné podniky. EUROUNION spol. s r.o,., September 2005, ISBN 80-88984-84- X

[11] Vojtovič, S., 2012 Potenciál kreatívneho priemyslu v regióne. In.: Sociálno-ekonomická revue. Roč. 10, č.2, s. 134-141. ISSN 1336-3727

[12] https://ec.europa.eu/regional_policy/en/information/maps/regional_competitiveness/

[13] http://www.statistics.sk

[14] http://www.sbagency.sk/sba-0

[15] https://www.siea.sk/databaza-technologickych-klastrov/,

[16] https://www.siea.sk/databaza-klastrov-v-cestovnom-ruchu/ 